\title{
アレー微動観測に基づく仙台市とその周辺地域での 地下深部 S 波速度構造の推定 \\ ESTIMATION OF S-WAVE VELOCITY STRUCTURES OF DEEP UNDERGROUND IN THE SENDAI REGION BASED ON ARRAY MEASUREMENTS OF MICROTREMORS
}

\author{
佐藤 智 美*1, 川瀬 博*2, 松島 信一*3, 杉村 義 広*4 \\ Toshimi SATOH, Hiroshi KAWASE, Shinichi MATSUSHIMA \\ and Yoshihiro SUGIMURA
}

\begin{abstract}
Array measurements of microtremors were performed at six sites in the Sendai region. Using the microtremors we calculate phase velocities of Rayleigh wave by F-K spectral analysis in the frequency range from 0.5 to $3.0 \mathrm{~Hz}$. Then we invert $S$-wave velocity structures from the seismological bedrock to the engineering bedrock by fixing the surface ground structures which are already known. As a result, well-controlled thicknesses of two layers are obtained at four sites. The thicknesses at the other two sites are estimated by using the microtremors together with the site responses derived from strong motion records.
\end{abstract}

Keywords: microtremor, array measurement, underground structure, F-K spectral analysis, Sendai, site response

微動, アレー観測, 地下構造, F-Kスペクトル解析, 仙台, サイト増幅率

\section{1. はじめに}

人口約 100 万人を有する仙台市とその周辺地域は、過去には 1978 年宮城県沖地震(M7.4)をはじめとする海洋型の大地震の被害を被っ ており1)、また、その中心部を縦断する活断層(長町一利府線2)にに対 してはその断層長さか.らマグニチュード7.2の地震が想定され 3 、地 震危険度解析により再現期間 2900 年で $600 \mathrm{Gal}$ 以上の最大加速度が推 定されるなど4)、地震防災上の観点から定量的地震動予測が重要な 地域のひとつである。

これまで筆者らは、仙台市を中心とした20×20k m²内にある 12 地 点でのボアホール強震記録を用いて、震源特性、伝播特性、地震 基 盤から工学的基盤までの増幅特性の分離を行い、これらの特性の平 均值と標準偏差を考慮した工学的基盤での統計的な強震動予測モデ ルを提案してきた5)。この際得られた12地点での地震基盤から工学 的基盤までの増幅特性は地点毎に少しずつ異なっており、地震基盤 から工学的基盤までの深い地下構造の違いを反映しているものと考 えられる6)。より精度よい強震動予測のためには、このような深い 地下構造の違いを考慮した地盤応答解析が必要である。しかし、仙 台ではこれまで反射法や屈折法といった大規模な地下構造探査が行 われておらず、その深い地下構造はほとんどわかっていない。
強震記録を用いて深い地下構造を推定する試みもなさ扎ているが 7),8)、これらの研究成果には以下のような問題がある。渋谷7)は岩盤 上の観測点に対する堆積地盤上での観測点のスペクトル比から仙台 市内8箇所でのS波速度 $830 \mathrm{~m} / \mathrm{sec}$ の層の層厚を推定しているが、そ れ以深の地下構造は推定されていない。竹沢ら8)はボアホール強震 観測点でのスペクトルをKobayashi and Midorikawa9)の地震基盤 スペクトルで除して得られるものとP波の走時解析とを併せて、S波 速度 $700 \mathrm{~m} / \mathrm{sec}$ の層の層厚は仮定してその下のS波速度 $1500 \mathrm{~m} / \mathrm{sec}$ の層の層厚の推定を試みている。しかし、Kobayashi and

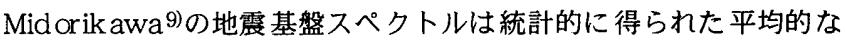
ものであり、このスペクトルで除したものが地盤の増幅率という仮 定は個々の地震の震源特性の違いや、伝播特性の地域性を無視して おり、そ扒はすべて增幅率におしつけられてしまうという問題があ る。また、P波走時解析を併用しているが、筆者らが同じ観測点で の記録を吟咮した結果、時間の精度が十分でないことが確認されて おり、得られた結果の精度に疑問がある。

一方、反射法や屈折法といつた地下構造探査と比較して簡便・安 価で振動による環境問題がなく、かつ、地盤解析に重要なS波速度 が推定できるアレ一微動探查が、各地で実施され成果を収めている
*1 大崎総合研究所 主任研究員 $\cdot 工$ 工博

*2 大崎総合研究所 主席研究員・I博

$* 3$ 大崎総合研究所 研究員.工修

*4 東北大学大学院工学研究科都市・建築学専攻 教授・I博
Chief Researcher, Ohsaki Research Institute, Inc., Dr. Eng.

Senior Researcher, Ohsaki Research Institute, Inc., Dr. Eng.

Researcher, Ohsaki Research Institute, Inc., M. Eng.

Prof., Urban Planning and Building Engineering, Graduate School of Engineering,

Tohoku Univ., Dr. Eng. 
的えば10) 14)。笋者らも、表層地盤檴造がPS检居により 既知であり 深い地下幥造も近傍の樑層ボーリングや発破探疽などによりほぼわ かっている江東区越中島においてアレ一微動撜育を行いその有効性 を夷証し15),16)、ノースリッジ地得や兵庫県南部地霞の被害地域で の適用を行ってきている17) 19)。

そこで、本研究では、仙台市とその周辺地域においてアレー微動 探査を行い地下樑部S波速度榜造の推定を行った。また、籍者ら5),6)

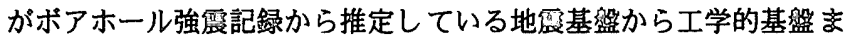
での増幅特性と得られた地下静造との対応関係についても検討した。

なお、本研究の一部は1997年地球惑星科学関連学会合同大会で発 表している20)。

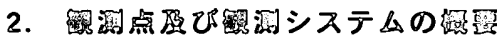

アレー微锄锶測点は等者ら5),6)がポアホール強哀記録から推定し

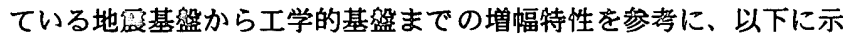

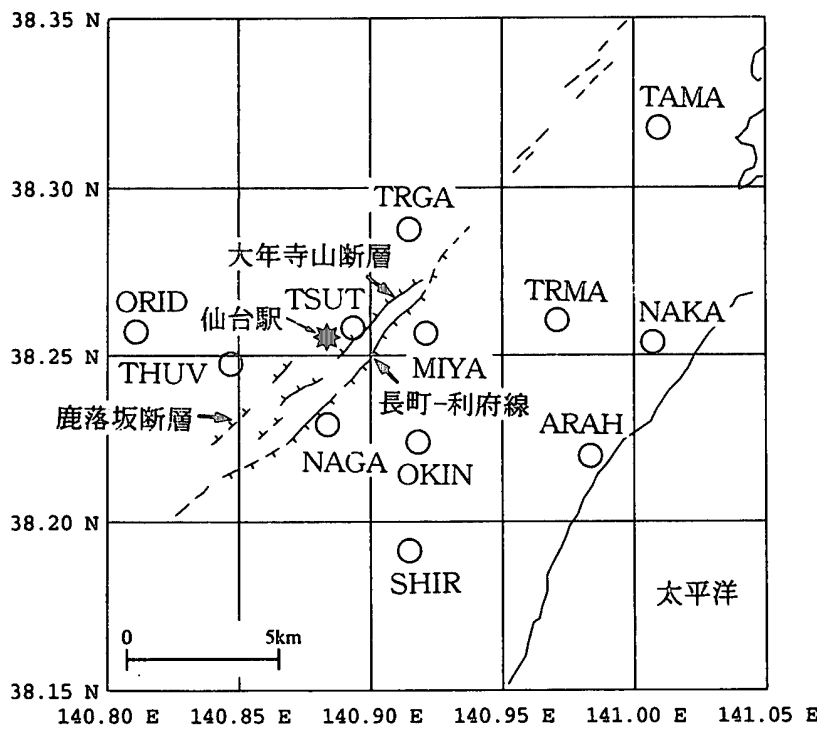

図1 等者ら5),6)が地震基然から工学的基盤までの増幅特性を推定し ているポアホール強需観測点位置（白丸で表示）
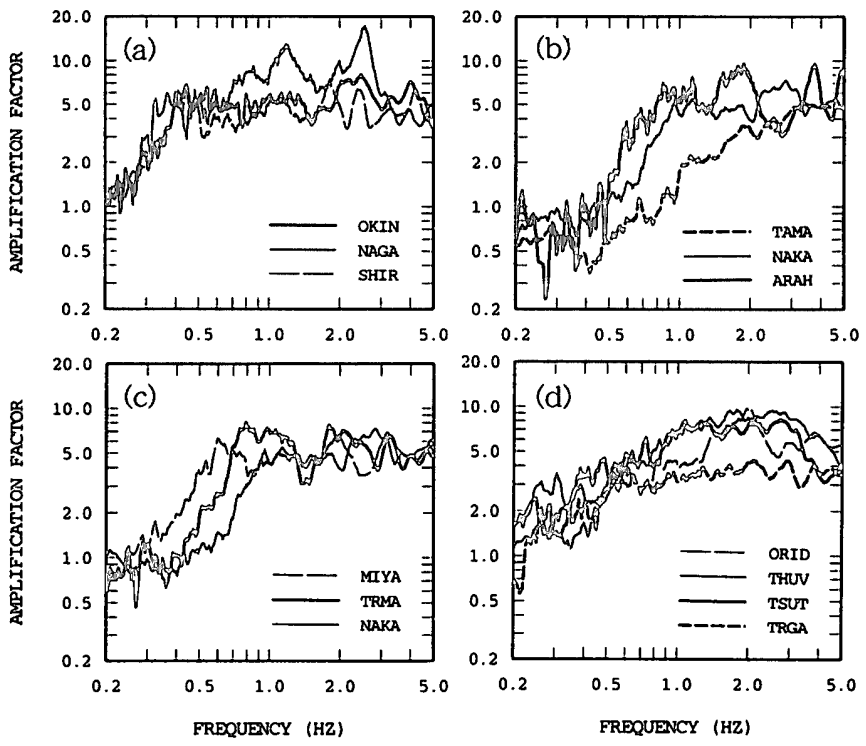

図2 地霞基然から工学的基盤までの増幅特性5),6)
すような判断に基づき選択した。ここで、工学的基盤とは仙台周辺 に共通に存在する新第三紀首上面でS波速度Vs>約 $500 \mathrm{~m} / \mathrm{sec}$ かつ 值>50の地盤である5)。図 1にはその 12観測点の位置21),22)を活断層 とともに示す。仙台市中心部には長町一利府線と呼ばれる北西上が りただし、北東方延長部では逆に南東上がり)の逆断層が存在し、 その北西側に大年寺山断層と鹿落坂断㜿という副断圆をともない、 現在も活针的であるとされている2),23),24)。12観測点の表層地盤は、 長町一利府線を境として西側では洪䅡層あるいは新第三紀の岩、東 側では沖䅡層から成っているが最北のTAMAの極表層下は新第三紀 前期中新世の岩となっている21),24)。

図2には等者ら5,6)が推定している地霞基盃から工学的基盃までの 増幅特性を示す。これは上述の定竓に基づく工学的基盤から地表ま での增幅特性の影淛を1次元波動理諭により取り除いた、工学的基 皿が愘頭している場合の增幅特性である。いずれも、ある周波敏ま では周波效が高くなるほど増幅察が増大し、その周波数より高周波 数ではほぼ平坦な增幅特性をもつ。この周波效は深い地下梅造の違 いを反映した地篮の1次卓越周波败に対応しているものと考えられ

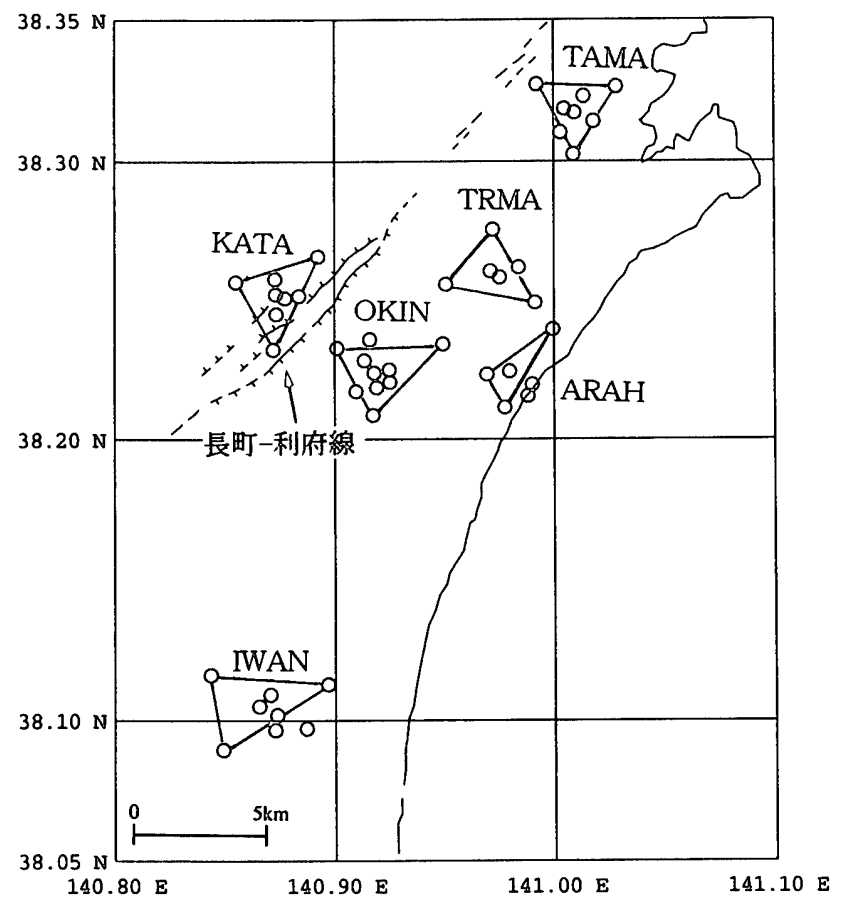

図36つの地域のLアレーの微動観測点のうち解析に用いた観測点 位疊(外側の3点を結んで表示)

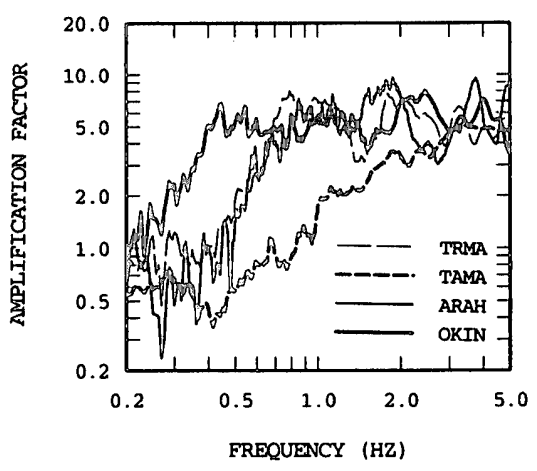

図4 アレー微動锶測を実施したOKIN,ARAH,TRMA,TAMAで推 定されている地霞基艠から工学的基盘までの增幅特性5),6) 
る。(a)の長町一利府線の東側の3つの観測点OKIN,NAGA,SHIRの増 福特珄は類似しており、0.3 0.4Hz付近に1次卓越周波数がある。 OKIN, NAGA,SHIRより東のARAHでは、1次卓越周波数がこれら3 つの観測点より高くなり、(b)に示したようにARAHからNAKA, TAMAと北上するにつれより高周波数側に移行する。また、(c)に示 した東側の観測点のうち北側のMIYA,TRMA,NAKAでは南側の OKIN, NAGA,SHIRと比較して1次卓越周波数が高く、東にいくほ ど高周波数側に移行する。これに対して(d)に示した長町一利府線の 西側の 4つの観測点.ORID,THUV,TSUT,TRGAでは1次卓越周波数 は顕著ではないものの、東側のOKIN,NAGA, SHIRと比較して1次 卓越周波数は高周波数側にある。平均的 S波速度を同じと仮定する と1次卓越周波数は基盤深さに対応する。このような仮定に立つと、 長町一利府線の東側では海岸側の方が基盤深さが浅く、また北にい くほど浅くなること、長町一利府線の南よりの地域では長町一利府線 をはさんだ西側の方が東側より基盤深さが浅いことが推測される。

アレー微動観測は仙台市とその周辺地域にある6つの地域で、そ れぞれ2つの異なるサイズのアレーにより観測を行った。以後小さ い方のアレーをSアレー、大きいほうのアレーをLアレーと呼ぶもの とする。図3には6つの地域のLアレーの観測点のうち解析に用いた

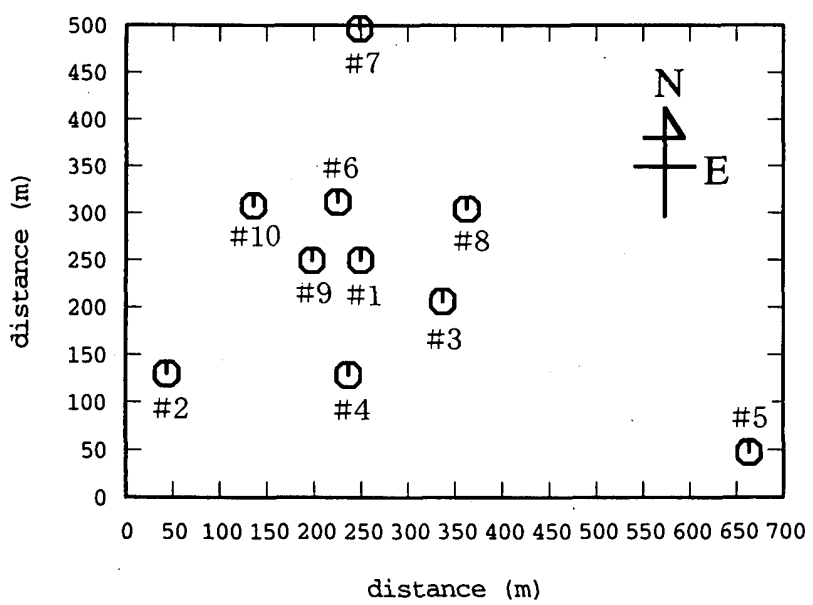

図5ＯKINのSアレーの観測点配置

表1 アレー微動観測点とテータの概要

\begin{tabular}{|c|c|c|c|c|c|c|c|}
\hline \multicolumn{2}{|c|}{ 観測点 } & $\begin{array}{c}\text { 観測開始 } \\
\text { 時間 } \\
\text { (月/日, 時:分) }\end{array}$ & $\begin{array}{l}\text { 観測 } \\
\text { 点数 }\end{array}$ & \begin{tabular}{|l|} 
最小観 \\
測点間 \\
距離(m)
\end{tabular} & $\begin{array}{l}\text { 最大観 } \\
\text { 測点間 } \\
\text { 距嚁(m) }\end{array}$ & $\begin{array}{l}\text { インパージョ } \\
\text { ンに用いた } \\
\text { 周波数 }(\mathrm{Hz})\end{array}$ & $\begin{array}{l}\text { 解析対象 } \\
\text { 時間区間 } \\
\text { 数 }\end{array}$ \\
\hline \multirow[t]{2}{*}{ KATA } & s & $8 / 26,21: 53$ & 10 & 64 & 508 & $1.0 \sim 2.4$ & 62 \\
\hline & L & $9 / 1,11: 25$ & 8 & 478 & 3778 & $0.5 \sim 0.7$ & 83 \\
\hline \multirow[t]{2}{*}{ OKIN } & S & $8 / 27,21: 47$ & 10 & 65 & 618 & $0.6-3.0$ & 73 \\
\hline & L & $8 / 27,23: 55$ & 10 & 609 & 4100 & $0.5 \sim 0.6$ & 84 \\
\hline \multirow[t]{2}{*}{ ARAH } & S & $8 / 28,22: 16$ & 9 & 48 & 662 & $0.6 \sim 2.0$ & 45 \\
\hline & $\mathrm{L}$ & $8 / 29, \quad 0: 19$ & 6 & 759 & 2993 & $0.5 \sim 0.6$ & 61 \\
\hline \multirow[t]{2}{*}{ TRMA } & $s$ & $8 / 29,22: 33$ & 7 & 57 & 631 & $0.9-1.8$ & 83 \\
\hline & $\mathrm{L}$ & $8 / 30, \quad 0: 44$ & 6 & 634 & 3495 & & 71 \\
\hline \multirow[t]{2}{*}{ TAMA } & s & $8 / 30,21: 17$ & 8 & 101 & 960 & & \\
\hline & L & $8 / 30,23: 15$ & 8 & 571 & 3036 & & 83 \\
\hline \multirow[t]{2}{*}{ IWAN } & $\mathrm{s}$ & $8 / 31,18: 8$ & 7 & 74 & 806 & $0.5-2.0$ & 83 \\
\hline & L & $8 / 31,21: 13$ & 8 & 652 & 4405 & $0.35 \sim 0.5$ & 83 \\
\hline
\end{tabular}

観測点を表示した。6つの地域のうちOKIN,ARAH,TRMA,TAMA の4地域では筆者らが地震基盤から工学的基盤までの地盤増幅率を 推定している地点を中心観測点とした。図4にはこの4地点での地震 基盤から工学的基盤までの增幅特性を改めて示す。長町一利府線の

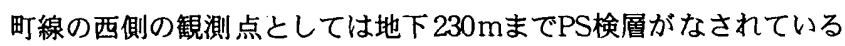
7,25) KATA(東北大学片平地区)を中心観測点として選んだ。KATA のLアレーのほぼ東端にTSUTが位置している。ARAH,OKIN, KATA は長町一利府線にほほ直交方向に並ぶ。長町-利府線にほほ平 行するラインとして、TAMA,TRMA,OKINの他、その南に位置す るK-net観測点であるIWAN (K-net観測点MYG015、岩沼市役所駐 車場)を中心観測点とした観測も行った。以上の6つの地域は、アレー 微動観測の中心点の表層地盤構造か既知であるという共通点がある。

図5にはOKINでのSアレーの観測点配置を示す。中心点の周りに3 つの異なるサイズの三角形を配置した10点での同時観測を行ってい る。表1に6つの地域でのアレ一観測点の概要を示す。6つの地域のL アレー、Sアレーともこのようなアレー配置を計画していたが、 ARAHのSアレ一観測途中からの豪雨のため1部の器材が不調となり それ以降の観測では表1、図3に示すように解析に使用できる観測点 数が少なくなった。計画よりもやや不規則な配置となったため、表 1の最大観測点間隔は外側のアレーの最大と次に最大の観測点間の 平均値、最小観測点間隔は最小と次に最小の観測点間の平均值を示 した。Sアレーではサンプリング周波数 $100 \mathrm{~Hz}$ で29分の速度波形の 連続観測、Lアレーはサンプリング周波数 $50 \mathrm{~Hz}$ z 58 分の変位波形の 連続観測を行った。観測点位置はSアレーではティファレンシャル GPSにより測定し、Lアレーでは1万分の1の地図から読み取った。

使用したシステムは、コントロール局からの無線指令により各観 測点に配置した収録装置(東京測振製CR-650)が収録を開始する無線 制御システムである。刻時信号も枌おきに無線で発信されるため、 たとえ無線によるトリガーがかからなかったとしても記録の同時性 を確保できる。収録装置による各地点での収録には内蔵水銀電池で バックアップされたICカードを用いている。センサーは成分のフィー ドバック型速度計(東京測振製VSE-11C,12C,40秒型)であり、0.025 〜 70Hzでフラットな振幅特性をもつ。

\section{3. 锶测記録の概要と $\mathrm{F}-\mathrm{K}$ 解析}

Sアレーでは40.98秒、Lアレーでは81.96秒の時間区間で半幅を オーパーラップさせながら波形を切り出し、それぞれの区間の波形

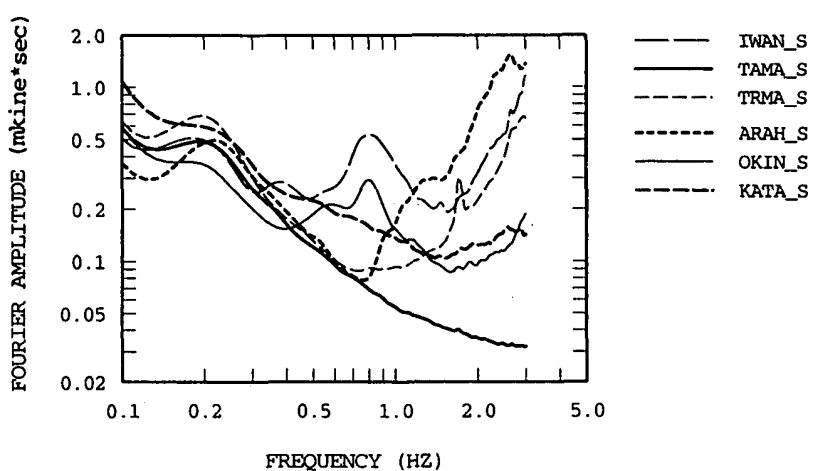

図6 6つの地域のSアレーで観測された波形の速度フーリエスペク トル(40.96秒の時間区間で切り出されたSアレーの全区間・全 観測点のスペクトルの平均值) 


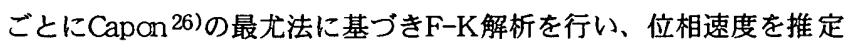

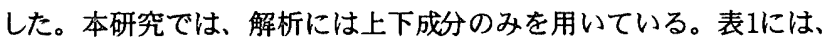
F-K解析を行った各篗則点での時間区関效を示す。図6には、Sアレー の全観測点での時間区分した全データの速度フーリエスペクトルの 平均値を $6 \supset$ の地域每に示す。地下 $33 \mathrm{~m}$ でS波速度 $1400 \mathrm{~m} / \mathrm{sec}$ 岩が 存在するTAMA ${ }^{21)}$ では高周波数領域でのレベルが他の锶測点と比皎 して $1 / 3 \sim 1 / 50$ と小さという特徵が見られる。一方、0.3Hz以下 では锶測点による差は非常に少なくなっている。図7にはOKINのS アレーの0.5 3Hzの速度フィルター波を例として示す。10観測点に おいて波形形状が穎似していることが確認できる。

図8に得られた $\mathrm{F}-\mathrm{K}$ スペクトルの例を示す。 $2.0 \mathrm{~Hz} 、 1.2 \mathrm{~Hz}$ 、 $0.9 \mathrm{~Hz}$ は図7に示した時間区間(OKNNのSアレー)でのF-Kスペクトル であり、0.55HzはOKINのLアレーで得られたF-Kスペクトルであ る。F-Kスペクトルが最大ピークとなる波数から位相速度を算出し ている。最大ピークとなる波数は 0 から図6に示したようなあらか じめ指定した波数の笾囲で探索されるため、位相速度の最小值は指 定した波㜟により規定されるが、最大値は無限大まで求まる可能性 がある。実際、Lアレーの低周波数領域では、レイリ一波の位相速 度としては物理的に考えられない大きな位相速度が推定されるケー スがあった。上部地款のS波速度は $3500 \mathrm{~m} / \mathrm{sec}$ 程度と考えられてお り27)、レイリー波の基本モードの位相速度がこれより大きいことは 物理的に考えられないこと、最大観測点間隔が最大波長のほほ $1 / 2$ 以下となることから、位相速度 $4500 \mathrm{~m} / \mathrm{sec}$ 以上のデータは除いた。 周波数が低くなるほど除かれるデー夕は増大する傾向にあるが、イ ンバージョンに用いた周波数䉇囲(表1)では、除かれたデー夕はほと んどの場合效\%以下である。

$\mathrm{F}-\mathrm{K}$ 解析により得られた各時間区間毎の位相速度分布をヒストグ ラムにしたものをOKINを例に図9に示す。横軸は位相速度 $(\mathrm{m} / \mathrm{sec})$

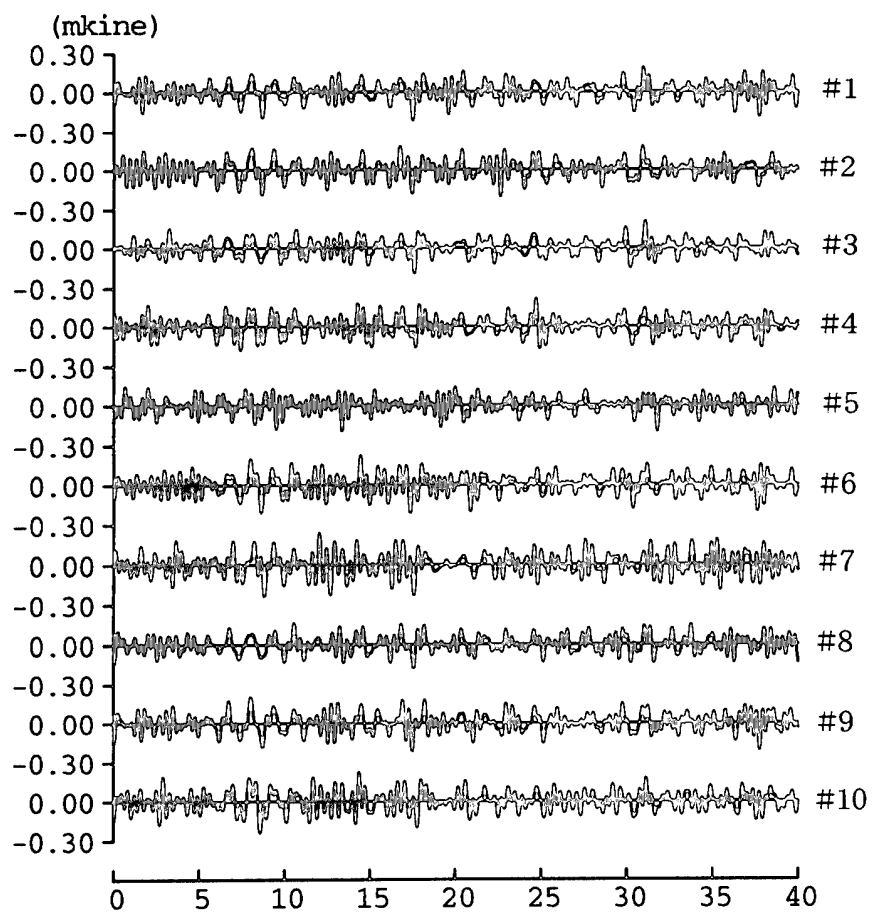

図7ＯKINのSアレーで観測された速度波形の例(0.5〜3.0Hzのフィ ルター波)
の対数の值である。2.0Hz、1.2Hz、0.9HzはSアレー、0.55HzはL アレーから推定された位相速度である。なお、Lアレーの $0.55 \mathrm{~Hz} の$ ケースでは、位相速度 $4500 \mathrm{~m} / \mathrm{sec}$ 以上のデータはない。位相速度の 対数を横軸にするとほぼ対称形となるが、ややとび離れたデタが いくつかみられる。そこで、対数で位相速度の平均值と標準偏差を 求め、これを用いて有為水準0.05のトンプソン棄却検定28ににより とび離れたデータが母集団本来のばらつきの簛囲内であるか否かの 検定を行った。そして、ばらつきの筑囲外と検定されたデー夕を除 いて再び対数で平均值と標準偏差を求めこれを観測值とした。図9 のヒストグラムにおいて黒塗のデータが検定により除かれたデータ である。表 1 に示したインバージョンに用いた周波数筑囲内では、 各周波数毎に数\%のデータが除かれている。

以上のようにして推定された位相速度の平均値と標準偏差を OKINのSアレーとLアレーについて図10に示す。図10には両アレー
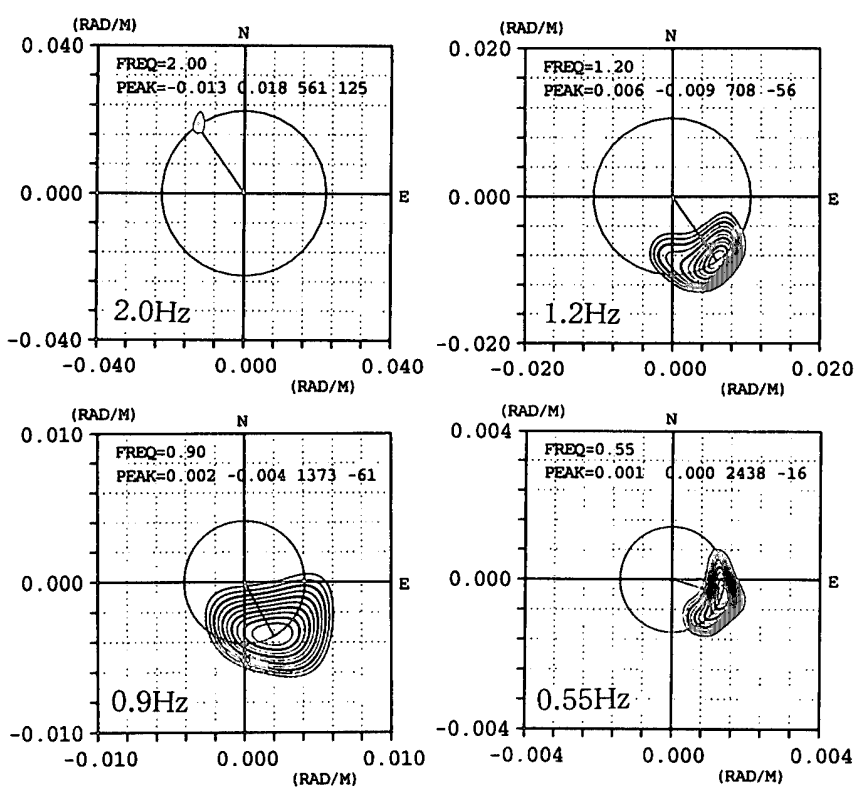

図8 OKINで観測された微動のF-Kスペクトルの例
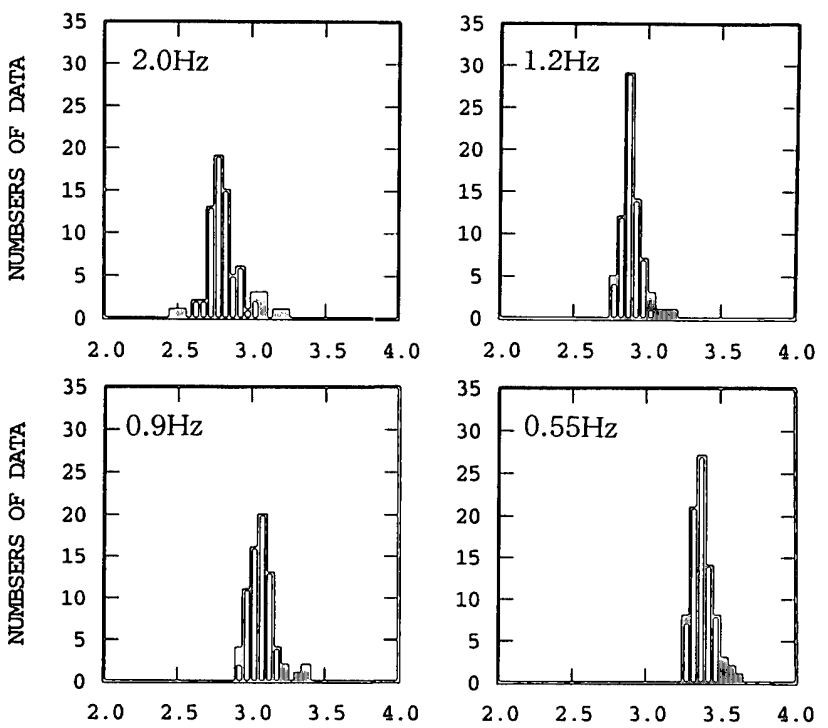

LOG (PHASE VELOCITY (M/SEC))

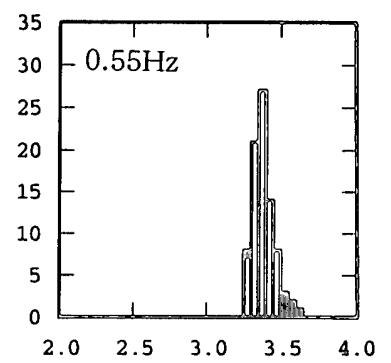

LOG(PHASE VELOCITY (M/SEC)) ンプソン棄却検定により除かれたデータ) 
のナイキスト周波数から決まる高周波数側の検知限界10)も示した。 Sアレーの最大周波数、Lアレーの最小周波数は、両者の位相速度が ほぼ一致する周波数範囲をとった。Sアレーの最小観測点間隔の5〜 6倍の波長まで推定位相速度はLアレーのものとほぼ一致している。 ARAHとIWANでもSアレーの最小観測点間隔の5〜6倍の波長でLア レーとほほ同じ位相速度が得られている。なお、KATA とTRMA で は、SアレーとLアレーで共通する周波数で安定した位相速度が得ら れていない。

図11には6つの地域で得られた位相速度の平均值を示す。TAMA のSアレーでは安定したF-Kスペクトルのピークがみられなかった ため、1Hz以上の高周波数領域での位相速度が推定されていない。 この原因として、上述のように(図6)、岩盤上の観測点であるTAMA の高周波数領域のスペクトルレベルが小さく、アレー内をコヒーレ ントに伝播する波動が少なかった可能性が考えられる。

\section{4. 地下権造の推定}

位相速度の平均值とレイリー波の基本モードがあうように修正準 ニュートン法29)によりS波速度構造のインバージョンを行った。表 層地盤構造はPS検層結果21) とボアホール強震記録から同定されたS 波速度》,22)で固定し、これより深い地下構造を推定した。インバー ジョンの対象としたパラメータは、既往の文献に基づき仙台地域に 広く分布していると仮定した共通の2つの層の層厚である。ただし、

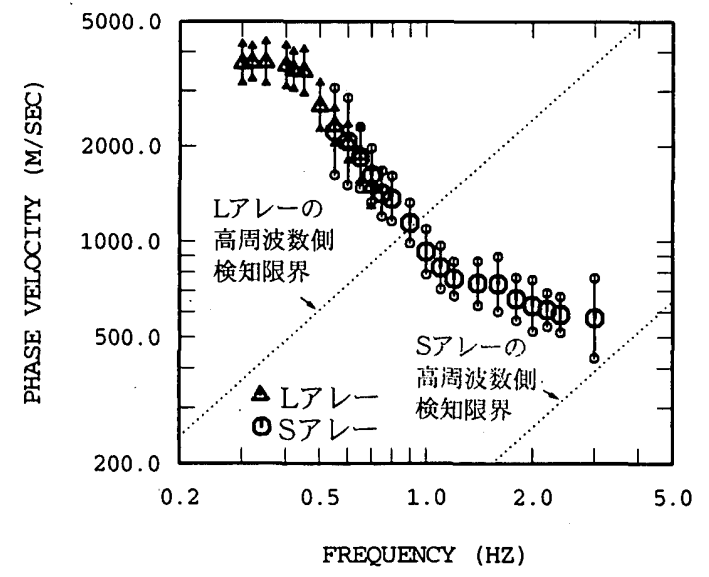

図10 OKINのSアレーとLアレーで推定された位相速度の平均値と 標淮偏差

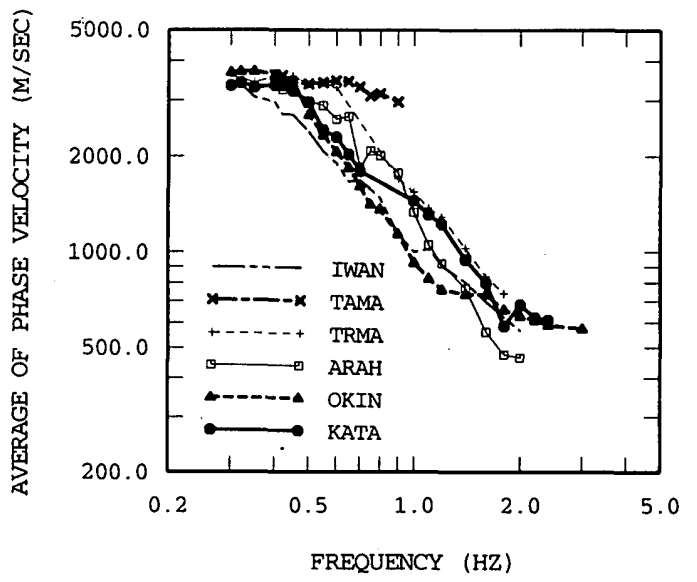

図11 6つの地域でのF-K解析により推定された位相速度の平均値

K-net観測点であるIWANでのPS検層は地下 $20 \mathrm{~m}$ までであり、共通 の層まで達していないため、地下 17〜20mに存在するS 波速度 $410 \mathrm{~m} / \mathrm{sec}$ 層の㕌厚もインバージョンの対象としている。

2層のうち上層のS波速度は $850 \mathrm{~m} / \mathrm{sec}$ と仮定したが、これは KATA で地下 $230 \mathrm{~m}$ でS波速度 $850 \mathrm{~m} / \mathrm{sec}$ 程度の層が連続している という PS検層結果に基づいているわ,25)。下層のS 波速度は $1700 \mathrm{~m} / \mathrm{sec}$ 仮定した。これは、IWANの南西約 $10 \mathrm{~km}$ の地点にお いてS波速度 $1600 \mathrm{~m} / \mathrm{sec} \sim 2000 \mathrm{~m} / \mathrm{sec}$ 層が地下約 $150 \mathrm{~m}$ から $400 \mathrm{~m}$ まで存在しているというPS検首結果30)と、TAMAの地下 $33 \mathrm{~m} に \mathrm{~S}$ 波 速度 $1400 \mathrm{~m} / \mathrm{sec}$ 層が存在しているというPS㭘層結果 211 に基づい ている。S波速度 $850 \mathrm{~m} / \mathrm{sec}$ の首は新第三紀鮮新世の仙台層群の下部

表2 地下構造(アンダーラインは推定したバラメータである層厚、 括弧内は強震記録に基づく推定値)

KATA

\begin{tabular}{|c|c|c|c|c|}
\hline \multicolumn{2}{|c|}{ 層厚(m) } & \multirow{2}{*}{$\begin{array}{c}\begin{array}{c}\text { S波速度 } \\
(\mathrm{m} / \mathrm{sec})\end{array}\end{array}$} & \multirow{2}{*}{$\begin{array}{l}\text { P波速度 } \\
(\mathrm{m} / \mathrm{sec})\end{array}$} & \multirow{2}{*}{ 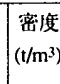 } \\
\hline 初期値 & 推定值 & & & \\
\hline \multicolumn{2}{|c|}{8.0} & 370.0 & 1200.0 & \\
\hline \multicolumn{2}{|c|}{92.0} & 00.0 & 000.0 & \\
\hline 100.0 & 200.1 & 850.0 & 2000.0 & \\
\hline \multirow[t]{2}{*}{800.0} & 597.7 & 1700.0 & 3300.0 & \\
\hline & & 3500.0 & 6100.0 & \\
\hline
\end{tabular}

OKIN

\begin{tabular}{|c|c|c|c|c|}
\hline \multicolumn{2}{|c|}{ 居厚(m) } & \multirow{2}{*}{$\begin{array}{l}\text { S波速度 } \\
(\mathrm{m} / \mathrm{sec})\end{array}$} & \multirow{2}{*}{$\begin{array}{l}\text { P波速度 } \\
(\mathrm{m} / \mathrm{sec})\end{array}$} & \multirow{2}{*}{$\begin{array}{l}\text { 密度 } \\
\left(\mathrm{t} / \mathrm{m}^{3}\right)\end{array}$} \\
\hline \begin{tabular}{l|} 
初期值 \\
\end{tabular} & 推定値 & & & \\
\hline \multicolumn{2}{|c|}{2.7} & 110.7 & 640.0 & 1.60 \\
\hline \multicolumn{2}{|c|}{3.3} & 110.7 & 1770.0 & 1.60 \\
\hline \multicolumn{2}{|c|}{2.0} & 250.1 & 2150.0 & 1.95 \\
\hline \multicolumn{2}{|c|}{3.8} & 467.2 & 2150.0 & 2.00 \\
\hline \multicolumn{2}{|c|}{2.1} & 227.0 & 2100.0 & 1.65 \\
\hline \multicolumn{2}{|c|}{2.8} & 227.0 & 2100.0 & 1.80 \\
\hline \multicolumn{2}{|c|}{5.3} & 415.5 & 2000.0 & 2.00 \\
\hline \multicolumn{2}{|c|}{19.8} & 530.1 & 2000.0 & 2.10 \\
\hline \multicolumn{2}{|c|}{7.8} & 653.3 & 2000.0 & 2.10 \\
\hline \multicolumn{2}{|c|}{12.4} & 562.8 & 1600.0 & 2.00 \\
\hline 100.0 & 351.1 & 850.0 & 2000.0 & 2.10 \\
\hline \multirow[t]{2}{*}{800.0} & 677.4 & 1700.0 & 3300.0 & 2.34 \\
\hline & & 3500.0 & 6100.0 & 2.70 \\
\hline
\end{tabular}

\begin{tabular}{|c|c|c|c|c|}
\hline \multicolumn{2}{|c|}{ 層厚(m) } & \multirow{2}{*}{$\begin{array}{c}\begin{array}{c}\text { S波速度 } \\
(\mathrm{m} / \mathrm{sec})\end{array}\end{array}$} & \multirow{2}{*}{ 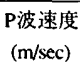 } & \multirow{2}{*}{\begin{tabular}{|c|} 
密度 \\
$\left(\mathrm{t} / \mathrm{m}^{3}\right)$
\end{tabular}} \\
\hline \begin{tabular}{l|} 
初期値 \\
\end{tabular} & 推定值 & & & \\
\hline \multicolumn{2}{|c|}{2.0} & 122.8 & 290.0 & 1.70 \\
\hline \multicolumn{2}{|c|}{4.0} & 161.0 & 1570.0 & 1.80 \\
\hline \multicolumn{2}{|c|}{8.0} & 261.4 & 1570.0 & 1.80 \\
\hline \multicolumn{2}{|c|}{6.9} & 192.1 & 1570.0 & 1.75 \\
\hline \multicolumn{2}{|c|}{4.9} & 192.1 & 1150.0 & 1.75 \\
\hline \multicolumn{2}{|c|}{5.3} & 105.5 & 1150.0 & 1.75 \\
\hline \multicolumn{2}{|c|}{3.9} & 397.4 & 1660.0 & 1.95 \\
\hline \multicolumn{2}{|c|}{14.7} & 570.0 & 1660.0 & 1.90 \\
\hline \multicolumn{2}{|c|}{25.9} & 610.0 & 1880.0 & 1.85 \\
\hline 200.0 & 180.2 & 850.0 & 2000.0 & 2.10 \\
\hline \multirow[t]{2}{*}{400.0} & $\underline{294.4}$ & 1700.0 & 3300.0 & 2.34 \\
\hline & & 3500.0 & 6100.0 & \begin{tabular}{|l|} 
\\
\end{tabular} \\
\hline
\end{tabular}

工学的基盤位置 22
TRMA

\begin{tabular}{|c|c|c|c|c|}
\hline \multicolumn{2}{|c|}{ 層厚(m) } & \multirow{2}{*}{$\begin{array}{l}\text { S波速度 } \\
(\mathrm{m} / \mathrm{sec})\end{array}$} & \multirow{2}{*}{$\begin{array}{c}\text { P波速度 } \\
(\mathrm{m} / \mathrm{sec})\end{array}$} & \multirow{2}{*}{$\begin{array}{c}\text { 密度 } \\
\left(\mathrm{t} / \mathrm{m}^{3}\right)\end{array}$} \\
\hline 初期値 & 推定值 & & & \\
\hline \multicolumn{2}{|c|}{1.3} & 87.4 & 290.0 & 1.60 \\
\hline \multicolumn{2}{|c|}{0.7} & 87.4 & 290.0 & 1.75 \\
\hline \multicolumn{2}{|c|}{2.3} & 87.4 & 690.0 & 1.75 \\
\hline \multicolumn{2}{|c|}{12.0} & 184.1 & 1630.0 & 1.75 \\
\hline \multicolumn{2}{|c|}{3.0} & 243.6 & 1630.0 & 1.70 \\
\hline \multicolumn{2}{|c|}{5.2} & 186.4 & 1630.0 & 1.70 \\
\hline \multicolumn{2}{|c|}{21.5} & 398.1 & 1870.0 & 1.90 \\
\hline \multicolumn{2}{|c|}{12.8} & 604.4 & 1870.0 & 2.00 \\
\hline \multicolumn{2}{|c|}{2.7} & 363.3 & 1870.0 & 1.80 \\
\hline \multicolumn{2}{|c|}{4.4} & 563.8 & 1870.0 & 2.00 \\
\hline \multicolumn{2}{|c|}{5.4} & 394.2 & 1870.0 & 1.85 \\
\hline \multicolumn{2}{|c|}{7.7} & 416.0 & 1870.0 & 1.90 \\
\hline 150.0 & $\underline{158.1}$ & 850.0 & 2000.0 & 2.10 \\
\hline 400.0 & $\frac{203.0}{(300)}$ & 1700.0 & 3300.0 & 2.34 \\
\hline & - & 3500.0 & 6100.0 & 2.70 \\
\hline
\end{tabular}

TAMA

\begin{tabular}{|c|c|c|c|c|}
\hline \multicolumn{2}{|c|}{ 居厚(m) } & \multirow{2}{*}{$\begin{array}{c}\text { S波速度 } \\
(\mathrm{m} / \mathrm{sec})\end{array}$} & \multirow{2}{*}{$\begin{array}{c}\text { P波速度 } \\
(\mathrm{m} / \mathrm{sec})\end{array}$} & \multirow{2}{*}{$\begin{array}{c}\text { 密度 } \\
\left(\mathrm{t} / \mathrm{m}^{3}\right)\end{array}$} \\
\hline 初期値 & 推定値 & & & \\
\hline \multicolumn{2}{|c|}{1.6} & 240.0 & 430.0 & 1.70 \\
\hline \multicolumn{2}{|c|}{1.2} & 570.0 & 1200.0 & 1.85 \\
\hline \multicolumn{2}{|c|}{2.9} & 570.0 & 1200.0 & 2.00 \\
\hline \multicolumn{2}{|c|}{4.8} & 870.0 & 1600.0 & 2.10 \\
\hline \multicolumn{2}{|c|}{14.5} & 870.0 & 2000.0 & 2.20 \\
\hline \multicolumn{2}{|c|}{7.5} & 1100.0 & 2500.0 & 2.25 \\
\hline & $(200)$ & 1700.0 & 3300.0 & 2.34 \\
\hline & & 3500.0 & 6100.0 & 2.70 \\
\hline
\end{tabular}

IWAN

\begin{tabular}{|c|c|c|c|c|}
\hline \multicolumn{2}{|c|}{ 層厚(m) } & \multirow{2}{*}{$\begin{array}{c}\text { S波速度 } \\
(\mathrm{m} / \mathrm{sec})\end{array}$} & \multirow{2}{*}{$\begin{array}{l}\text { P波速度 } \\
(\mathrm{m} / \mathrm{sec})\end{array}$} & \multirow{2}{*}{$\begin{array}{c}\text { 密度 } \\
\left(\mathrm{t} / \mathrm{m}^{3}\right)\end{array}$} \\
\hline 初期値 & 推定値 & & & \\
\hline \multicolumn{2}{|c|}{2.0} & 100.0 & 370.0 & 1.56 \\
\hline \multicolumn{2}{|c|}{2.0} & 100.0 & 1600.0 & 1.62 \\
\hline \multicolumn{2}{|c|}{4.0} & 180.0 & 1600.0 & 1.74 \\
\hline \multicolumn{2}{|c|}{9.0} & 250.0 & 1600.0 & 1.85 \\
\hline 3.0 & 79.1 & 410.0 & 1600.0 & 1.97 \\
\hline 100.0 & $\underline{266.0}$ & 850.0 & 2000.0 & 2.10 \\
\hline 800.0 & $\underline{565.9}$ & 1700.0 & 3300.0 & 2.34 \\
\hline & & 3500.0 & 6100.0 & 2.70 \\
\hline
\end{tabular}



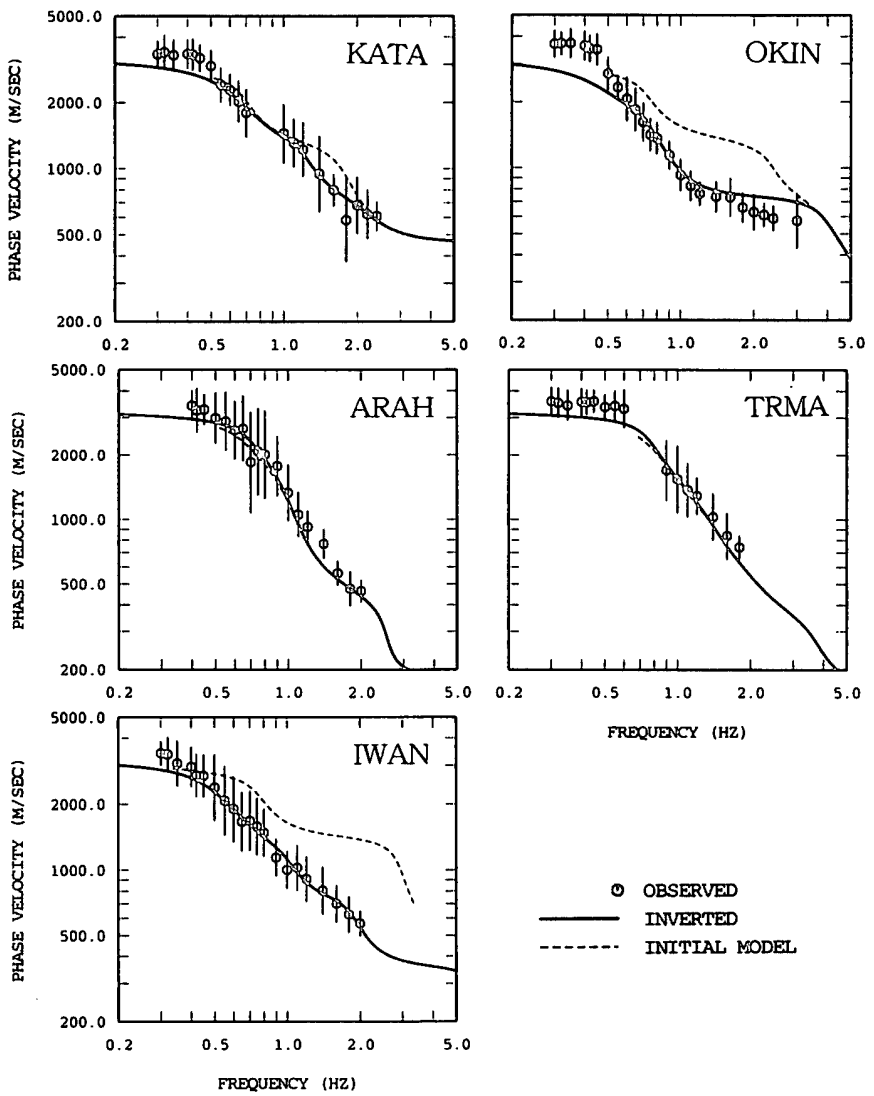

FRPQUENCY (HZ)

図12 F-K 解析により推定された位相速度の平均值と地下構造の初 期值及び推定值を用いたレイリー波基本モードの理論分散曲 線との対応関係

(竜の口層、冕岡層)、後期中新世の秋保層群、志田層群に相当し、S 波速度 $1700 \mathrm{~m} / \mathrm{sec}$ 層は中期・前期中新世の名取層群、松島湾層群 に相当するものと考えられる24),31)。基盤速度は、地廢の走時異常 のインバージョンから推定されている東北地方の上部地殼のP波速 度のコンターマップ32)と、北上山地での屈折法探㚗から推定されて いる上部地殻のP波速度とS波速度27)を参考に、P波速度 $6.1 \mathrm{~km} / \mathrm{sec}$ S波速度 $3.5 \mathrm{~km} / \mathrm{sec}$ とた。

パラメータとする層の層厚の初期值は、 $\mathrm{S}$ 波速度 $850 \mathrm{~m} / \mathrm{sec}$ 層厚 については溒谷》が推定した仙台市内8箇所でのS波速度 $830 \mathrm{~m} / \mathrm{sec}$ の層の層厚を参考にした。S波速度 $1700 \mathrm{~m} / \mathrm{sec}$ の層の層厚について は、図4に示したボアホール強霞記録から推定している地㞼基然か ら工学的基盤までの増幅特性5),6)を参考にした。表2に初期モデル 推定した層厚とともに示す。

図12には、TAMAを除く5つの観測点での F-K 解析に基づく位相 速度の平均值と標準偏差、初期モテルとインバージョンモデル基 づくレイリー波の基本モードの分散曲線を示す。表1にはインバー ジョンの对象とした周波数箱囲を示す。SアレーとLアレーの最小周 波数は、最小観測点間隔から決まるナイキスト周波数、及びF-K ス ペクトルに異なる速度を示す多数のピークがみられないことを考怒 して決定した。低周波数側の検知可能な周波数限界は最大観測点間 隔の1/2〜1/6の波長となる周波数といわれており例えば10),13),14),16)、

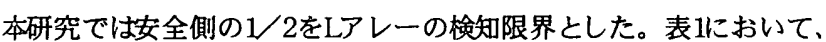
SアレーとLアレーで共通する周波数では両者で得られた位相速度が ほぼ一致しており、両者の平均値を解析に用いた。TRMAではS波

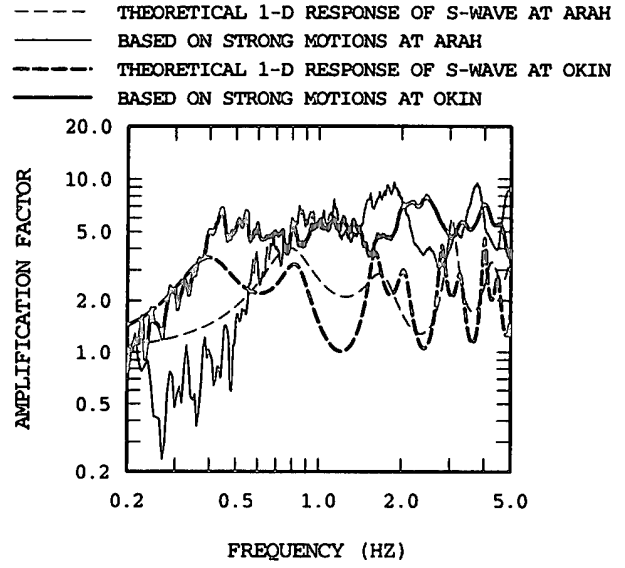

図13 OKINとARAHでの地篮基盤から工学的基盤までの増幅率

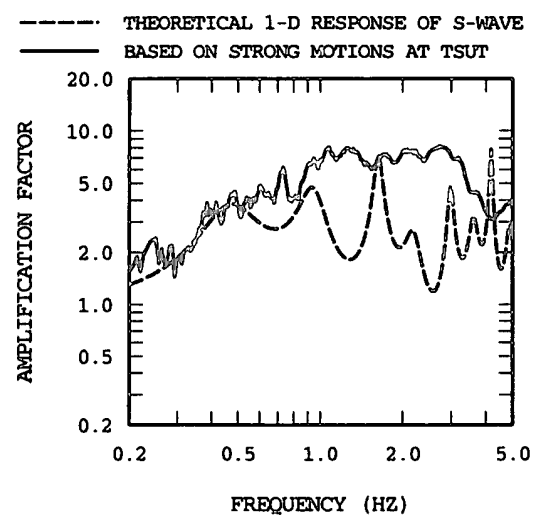

図14 KATAでの地霞基盤から工学的基盤までの増幅率(強震記録に 基づくものKATAに一番近いTSUTでのもの)

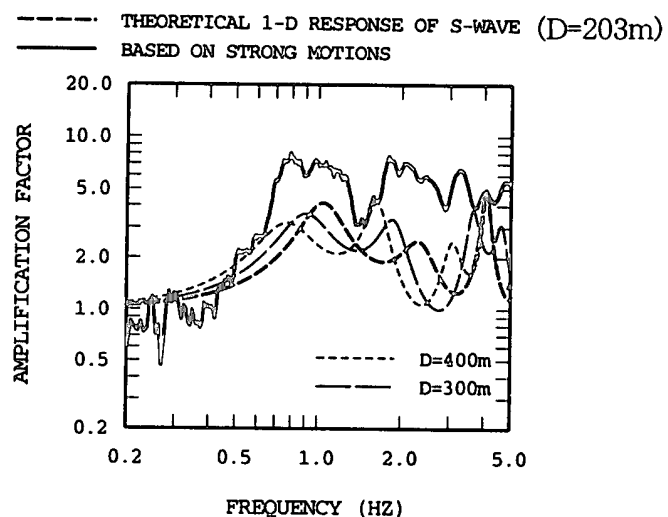

図15 TRMAでの地震基盤から工学的基盤までの増幅率(理論増幅率 ではS波速度 $1700 \mathrm{~m} / \mathrm{sec}$ 層厚Dを変化させた）

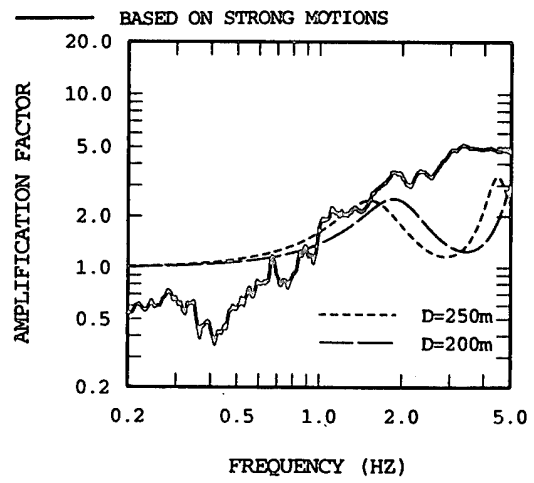

図16 TAMAでの地霞基盤から工学的基盤までの増幅率(理論増幅率 ではS波速度 $1700 \mathrm{~m} / \mathrm{sec}$ 層厚Dを変化させた） 
速度 $1700 \mathrm{~m} / \mathrm{sec}$ の首の層厚推定に重要な周波数において、F-K解析 により安定した位相速度が得られていないため、インバージョンは Sアレーで位相速度が求められている周波数帯域のみで行った。 OKINの高周波数領域を除いて、インバージョンモデルにより、 $\mathrm{F}-\mathrm{K}$ 解析に基づく位相速度がよく説明されていることが確認できる。 OKINの高周波数領域は、固定している表層S波構造を変化させない と合わせることができない。これは強震計が設置されているOKIN の表層構造が、OKINのSアレー領域の平均的な表層構造を代表して いない可能性を示唆している。

図13には、インバージョンに基づく地下構造を用いたS波の1次元 地盤增幅率と強震記録から推定されている增幅率との比較をOKIN とARAHについて示す。両者とも地震基盤( $(\mathrm{S}$ 波速度 $3500 \mathrm{~m} / \mathrm{sec}$ 基 盤から工学的基盤までの増幅率であり、前述の定義に基づく工学的 基盤の位置は表2に示した。なお、いずれも表2に示した位置で工学 的基盤が露頭している場合の增幅率である。OKINとARAHの強震 記録から推定された增幅率にみられた1次卓越周波数の違いが、理 論の増幅特性でほぼ説明できる。理論増幅率の1次卓越周波数の方 がやや小さい傾向があるが、これは鈶直入射の場合の計算であるか ら理論的に考えられるピーク周波数の最小值を意味しており、入射

\section{S-WAVE VELOCITY (KM/SEC)}
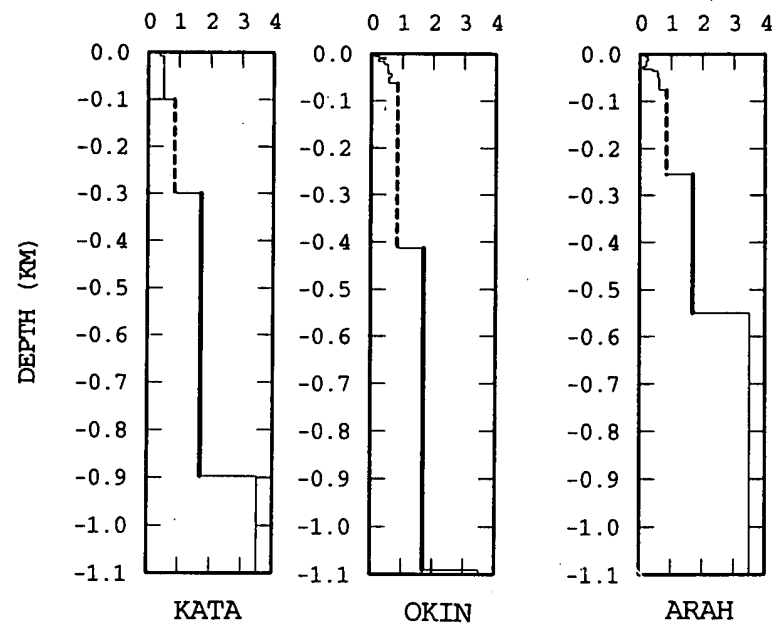

角の変動により高周波数側にシフトすることが期待される。増幅率 のレベルの差の原因として、理論に用いた地下構造の層数が少ない こと、理論計算で仮定した $Q=110 f 0.69$ が地震基盤から工学的基盤 までの地盤に対するものでないこと5)、強震記録から増幅率推定の 際の継続時間がJennings型包絡形にフィッテイングするように定 義されているため純粋な直達S波部分より長いこと5),22)などが考え られる。図14にはKATAでインバージョンされた地下構造を用いた S波の1次元地盤增幅率と、TSUT(図1)での強震記録に基づく地震 盤から工学的基盤までの増幅率の比較を示す。この場合も、両者の 増幅率の1次卓越周波数にはよい対応がみられる。

同様の增幅率の比較をTRMAについて図15に示す。太点線がイン バージョンされた地下構造を用いた理論增幅率であり、ARAHや OKINと比較して強震記録から推定された增幅率との一致度が悪い。 上述のようにTRMAでは微動テータによりS波速度 $850 \mathrm{~m} / \mathrm{sec} の$ 首の 層厚は拘束がきいて求められているが、 $\mathrm{S}$ 波速度 $1700 \mathrm{~m} / \mathrm{sec} の$ 層の 層厚の分解能が小さいためこの層の層厚をインバージョン結果の $203 \mathrm{~m}$ の他、300m、400mにした場合の理論増幅率も示した。S波速 度 $1700 \mathrm{~m} / \mathrm{s}$ 層を $300 \mathrm{~m}$ とした場合に強震記録に基づく増幅率と整 合する。TAMAでも、強震記録に基づく增幅率を用いてS波速度 $1700 \mathrm{~m} / \mathrm{sec}$ 層の層厚の推定を試みた。 $1700 \mathrm{~m} / \mathrm{sec}$ 層の層厚を 200、250mとした場合の理論増幅率と強震記録に基づく増幅率を図 16 に示す。200mの層厚で強震記録に基づく增幅率の1次卓越周波数 をほぼ説明できる。なお、このように強震記録に基づく増幅率を利 用して推定した層厚は表2に括弧内に表示した。また、このような 㕌厚を用いて計算されるRayleigh波基本モードの位相速度は、

TRMAのSアレー、TAMAのLアレーで得られた位相速度をほほ説明 できることを確認している。

以上のようにして得られたS波速度構造を長町一利府線に直交する 断面と平行する断面について図17に示す。TRMA、TAMAでの $1700 \mathrm{~m} / \mathrm{sec}$ 首厚は、強震記録から推定された增幅率をほぼ説明す る層厚(TAMA で $200 \mathrm{~m} 、$ TRMA で $300 \mathrm{~m}$ )を示した。長町一利府線の 西にあるKATAでの基盤深さは約 $900 \mathrm{~m}$ 、東にあるOKINでは $1100 \mathrm{~m}$ でありその差は約 $200 \mathrm{~m}$ 推定された。OKINから5.5km 東のARAH では基盤深さが $540 \mathrm{~m}$ 浅くなるという急激な変化がみられる。長

(a) 長町-利府線に直行方向

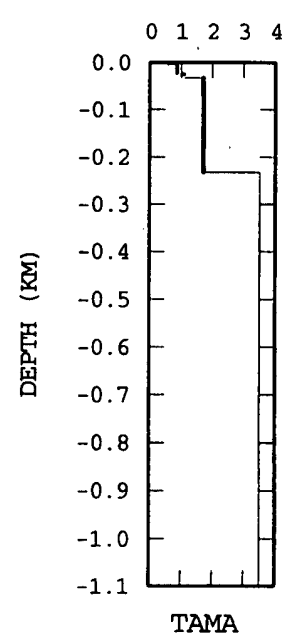

$\begin{array}{lllll}0 & 1 & 2 & 3 & 4\end{array}$

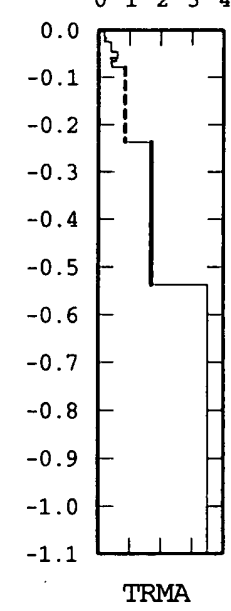

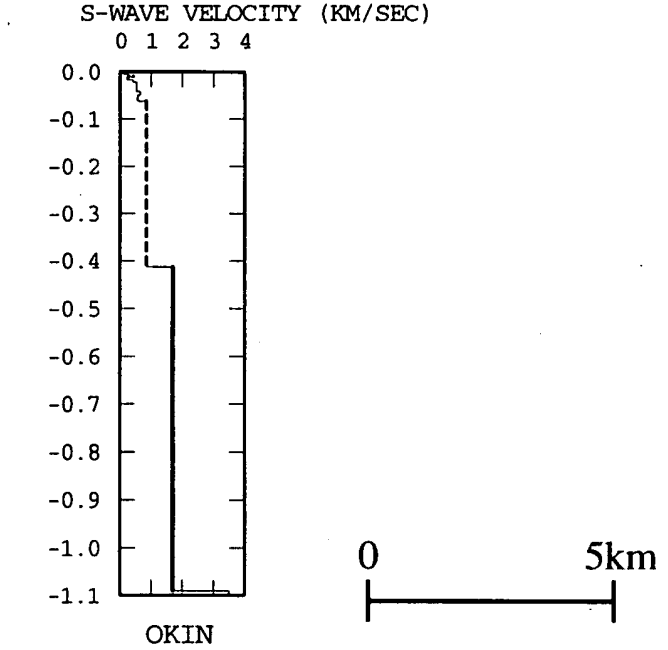

OCITY (KM/SEC)

(b) 長町-利府線に平行方向

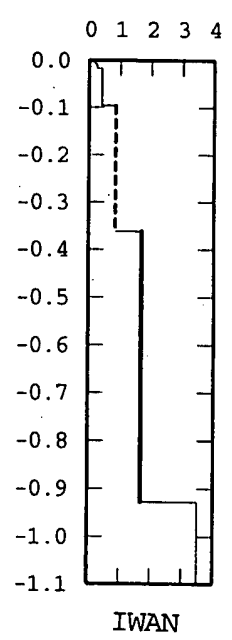

図176つの地域において推定された地下構造(太点線 $=\mathrm{S}$ 波速度 $850 \mathrm{~m} / \mathrm{sec}$ の層、太実線 $=\mathrm{S}$ 波速度 $1700 \mathrm{~m} / \mathrm{sec}$ 層) 
町一利府線に平行する断面では、北側のTAMAからTRMA，OKINと 南下するにしたがってS波速度 $850 \mathrm{~m} / \mathrm{sec}$ の層、 $1700 \mathrm{~m} / \mathrm{sec}$ 層と も層厚が厚くなり基盤深さが深くなることがわかる。TRMAの地下 構造はARAHと類似しており、6km離れているOKINとの基盤深さ の差が大きい。OKINから水平距離で13.6km離れているIWANでは 基盤深さが $920 \mathrm{~m}$ とOKINと比較してやや浅いもののその差は同程度 離れたTAMAとOKINの差と比べるとずっと小さい。

\section{5. まと的}

本研究では、深い地下構造がほとんど未知といってよい仙台市と その周辺の6地域でアレー微動観測を行い、地霞基盤に至る深い地 下構造の推定を試みた。その結果、4地域における地下樑部S波速度 耧造がアレ一微動観測記録により推定できた。そして、得られた地 下構造を用いたS波の1次元理論增幅率と筆者らがボアホール強䨓記 録から推定している地盤増幅率とはその周波数特性がよく対応する ことが確認された。この結果から、逆に、アレ一微動記録のみから は拘束のきいた地下樑部S波速度構造を推定することが困難であっ た残りの2つの地域でも、ボアホール強震記録から推定している地 盤增幅率の情報と併せることにより、その地下深部S 波速度構造の 推定を行うことができた。以上のようにして、仙台市中心部を南北 に縦断する長町-利府線をまたがる直交方向と東側の平行方向の地 下深部S波速度構造が推定された。

アレー微動観測後の1996年9月〜1997年4月にかけてOKIN周辺で アレー地震観測を実施しており、今後このデータをもとに今回得ら れた基盤深さ及び基盤上面のS波速度の検証を行う予定である。

\section{跳辞}

微動観測に際しては、清水建設の佐藤俊明・早川崇・渡辺基史・片岡俊一 の各氏、東北大学 工学部の三辻和弥・渡慶次ファンカルロス・井上尚大・徳 光完一・丸山倫幸の各氏の御協力を得ました。東北大学の栗田哲助教授には、 観測点選定に際して有意義なご助言を頂きました。建設省建築研究所の大川 出氏、鹿鳴俊英氏、小山信氏、東北大学の佐々木達夫技官には、観測点の観 測許可等に関して便宜をはかっていただきました。また、小・中学校の関係 者をはじめ多数の市民の方々に観測場所を提供して頂きました。この研究は、 このような多くの方々のお力添えがあってはじめて可能となったものであり、 心より感謝致します。また、建設省建築研究所と(社)建築研究振興協会の共同 研究として実施されている仙台高密度強震観測事業のボアホール観測点と防 災科学技術研究所のK-net観測点(MYG015)の表層地盤情報を使用させて頂き ました。

\section{参考文献}

1）宇佐美能夫：新編日本被害地霞総覧、東京大学出版会、1991.

2）活断層研究会編：新編日本の活断層一分布図と資料、東京大学出版会、 1991

3）松田時彦：活断層から発生する地震の規模と周期について、地震、第 28 巻、pp.269-283、1975.

4）石川裕、奥村俊彦: 活断層を考盧した主要都市の地震危険度評価、清水 建設研究報告、第64号、pp.33-40、1996.

5）佐藤智美、川瀬博、佐藤俊明 : 表首地盤の影響を取り除いた工学的基 搵波の統計的ス゚ペクトル特性, 仙台地域のポアホールで観測された多数 の中小地震記録を用いた解析、日本建築学会構造系論文集, No.462、 pp.79-89、1994.

6）佐藤智美、川瀬博、佐藤俊明：観測記録から同定した地霞動の統計的 特性と地酘の非線形性を考慮した強震動予测、日本建築学会構造系論文 集、No.463、pp.27-37、1994.

7）啮谷純一：地盤構造と強震動の破壊力特性に関する研究、東北大学博士 論文、 1985 .

8）竹沢要一、小林啓美、斉藤芳人、島田三朗 : 仙台地域における地震基盤 深さの推定、日本建築学会学術講演梗概集、pp.503-504、1991.

9) Kobayashi $H$. and S. Midorikawa : A semi-empirical method for estimating response spectra of near-field ground motions with regard to fault rupture, Proceedings of the Seventh European Conference on Earthquake Engineering, pp.161-168, 1982 .

10) Horike, M. : Inversion of phase velocity of long-period microtremors to the S-wave-velocity structure down to the basement in urbanized areas, J. Phys. Earth, Vol.33, pp.59-96, 1985.

11) Matsushima, T. amd H. Okada : Determination of deep geological structures under urban areas using long-period microtremors, Butsuri-Tansa, Vol.43, No.1, pp.21-33, 1990 .

12) Sato, T., H. Kawase, M. Matsui, and S. Kataoka : Array measurement of high frequency microtremors for underground structure estimation, Fourth International Conference on Seismic Zonation, Vol.II, pp.409-416, 1991.

13）山中浩明 武村雅之、石田寬、池浦友則、野澤贵、佐々木透、丹羽正徳 首都圈西部におけるやや長周期微動の観測とS波速度椣造の推定、地震、 第47巻、第2号、pp.163-172、1994.

14）時松孝次、新井洋、浅香美治：微動観測から推定した神戸市住吉地区の 深部S波速度構造と地震動特性、日本建築学会権造系論文集、No.491、 pp.37-46. 1997.

15）川瀨博、佐藤智美、片岡俊一、佐藤俊明、野田静男、真下貢 : アレ一筱 動による都市部における地下構造探査法(その1) 測定条件に対する検討、 日本建築学会大会学術講演梗概集、pp.493-494、1994.

16）佐藤智美、川濑博、片岡俊一、早川崇、西村功、中村亮一：アレ一微動 による都市部における地下構造探查法 (その2) 検知限界にに対する検討 と地下構造、日本建築学会大会学術鞮演梗概集、pp.495-496、1994.

17）川濑博、入倉孝次郎、岩田知孝、佐藤智美、早川崇 : 1994年ノースリッ 汢地震被害地域における地盤構造調查、日本地震学会講演予稿集、N No.2、 C28、1995.

18）佐藤智美、川瀬博、岩田知孝、入倉孝次郎 : アレイ微動観測による1994 年ノースリッジ地震被害地域における地下速度構造の推定、地震学会講 演予稿集、No.2、C18、1996.

19）片岡俊一、川瀬博：神戸市東灘区に扮ける微動と発破観測記録の表面波 解析、地球惑星科学関連学会合同大会予稿集、pp.126、1997.

20）佐藤智美、川瀨博、松島信一、杉村義広：アレー微動記録に基づく仙 台市とその周辺地域における地下構造の推定、地球惑星科学関連学会合 同大会予稿集、1997.

21) Kitagawa Y., I. Ohkawa, and T. Kashima : Dense array observation and analysis of strong ground motions at sites with different geological conditions in Sendai, BRI Research Paper, No.139, 1994.

22）佐藤智美、川濑博、佐藤俊明 : ボアホール観測記録を用いた表層地盤同 定手法による工学的基盤波の推定及びその統計的経時特性、日本建築学 会構造系論文集、No.461、pp.19-28、1994.

23）今泉俊明 : 東北地方南部の活断屏、西村勀助先生退官記念地理論文集、 pp.21-26、1980

24）北村信、石井武政、寒川旭、中川久夫 : 仙台地域の地質 地域地質研究 報告5万分の 1 地質図幅、地質調查所、1 1986.

25）平沢朋郎、山本清彦、石井紘、浅田秋江、橴谷純一、鉿木保典：仙台市 片平における地盤の弾性波速度測定、日本地霞学会講演予稿集、No.2, pp.197, 1981.

26) Capon J. : High-resolution frequency-wave-number spectrum analysis, Proc. IEEE, Vol.57, pp.1408-1418, 1969.

27) Iwasaki T., T. Yoshii, T. Moriya, A. Kobayashi, M. Nishiwaki, T. Tsutsui, T. Iidaka, A. Ikami, and T. Masuda : Precise $P$ and $S$ wave velocity structures in the Kitakami massif, Northern Honshu, Japan, from a seismic refraction experiment, J. Geophys. Res., Vol.99, No.B11, pp.2218722204, 1994.

28）石村貞夫：統計解析のはなし、東京図書、1994.

29) Fletcher, R. : FORTRAN subroutines for minimization by quasi-Newton methods, Report R7125 AERE, Harwell, England, 1972.

30）清水昭男、阿部健一、嶋田郕、粕田金一：KASSEM設置地点における 地盤定数と観測地震波の解析、熊谷技報、第39号、pp.111-122、1986.

31）生出慶司、藤田至則：岩沼地域の地質 地域地質研究報告5万分の 1 地質 図幅、地質調查所、1 1975.

32) Zhao D. : A study on the three-dimenstional crustal structure of the Northeastern Japan arc, 東北大学修士論文、1988.

（1997年 6 月 9 日原稿受理，1997年 8 月 6 日採用決定） 